\title{
Hubungan Tingkat Pengetahuan Ibu dan Tingkat Ekonomi Keluarga Nelayan dengan Status Gizi Balita di Kelurahan Air Tawar Barat Kota Padang
}

\author{
Pipit Amelia Burhani ${ }^{1}$, Fadil Oenzil ${ }^{2}$, Gusti Revilla ${ }^{3}$
}

\begin{abstract}
Abstrak
Status gizi memiliki pengaruh yang sangat besar terhadap kesehatan individu, sehingga mempengaruhi kualitas sumber daya manusia dimasa yang akan datang. Status gizi balita tergantung pada asupan gizi, tingkat pengetahuan ibu, tingkat ekonomi keluarga, pendidikan ibu, pola asuh dan ketahanan pangan. Tujuan penelitian ini adalah menentukan hubungan tingkat pengetahuan ibu dan tingkat ekonomi keluarga nelayan dengan status gizi balita. Penelitian ini dilakukan dari Juli 2014 sampai Januari 2015. Desain penelitian adalah cross sectional study dengan jumlah subjek 21 orang ibu balita. Data dianalisis secara univariat dengan tabel frekuensi dan analisa bivariat dengan tabel silang lalu diuji dengan uji korelasi Rank Spearman. Hasil penelitian ialah balita yang memiliki gizi kurus sebanyak 9,5\% dan yang memiliki gizi normal sebanyak 90,5\%. Pengetahuan ibu rendah sebanyak 52,3\% dan pengetahuan ibu tinggi sebanyak $47,6 \%$. Tingkat ekonomi keluarga didapatkan keluarga miskin sebanyak $95,2 \%$ dan keluarga tidak miskin sebanyak 4,8\%. Hasil uji statistik didapatkan tidak ada hubungan antara tingkat pengetahuan ibu dan tingkat ekonomi keluarga dengan status gizi balita.
\end{abstract}

Kata kunci: status gizi, balita, tingkat pengetahuan ibu, tingkat ekonomi keluarga

\begin{abstract}
Nutritional status has a profound influence in individual's health that affecting the quality of human resources in the future. Nutritional status depends on food intake, mother's knowledge, family economics, mother's education, nurturing pattern and food availability. The objective of this study was to determine the relationship level of mother's knowledge and fishermen's family economic with nutritional status of toddler. This research was conducted between July 2014 and January 2015 to 21 mothers with toddler. Cross sectional study was used as study design. Data were analyzed by univariate analysis with frequency tables and bivariate analysis with cross table using Rank Spearman. Result showed that $9.5 \%$ of the toddlers are under nutrition and $90.5 \%$ are normal. $52.3 \%$ of the mothers have low knowledge level whereas $47.6 \%$ are higher. $95.2 \%$ of the families are in the poverty line and $4.8 \%$ are not. It can be concluded that there is no relationship between level of mother's knowledge and fishermen economic with nutritional status of toddler.
\end{abstract}

Keywords: nutritional status, toddler, level of mother's knowledge, family economic

Affiliasi penulis: 1. Prodi Profesi Dokter FK UNAND (Fakultas Kedokteran Universitas Andalas Padang), 2. Bagian Biokimia FK UNAND, 3. Bagian Anatomi FK UNAND

Korespondensi: Pipit Amelia Burhani, Email:

pipitameliaburhani@gmail.com , Telp: 085272808192

\section{PENDAHULUAN}

Kesehatan adalah hak asasi manusia dan sekaligus merupakan investasi sumber daya manusia. Kesehatan yang baik serta menjadi suatu keharusan 
bagi semua pihak untuk memelihara, meningkatkan dan melindungi kesehatan demi kesejahteraan masyarakat. Kualitas sumber daya manusia dimasa yang akan datang sangat dipengaruhi oleh status gizi. Kekurangan gizi, menimbulkan masalah kesehatan (morbiditas, mortalitas dan disabilitas) dan menurunkan kualitas sumber daya manusia (SDM) suatu bangsa. Dalam skala yang lebih luas, kekurangan gizi dapat menjadi ancaman bagi ketahanan dan kelangsungan hidup suatu bangsa. ${ }^{1}$ Walaupun sumber daya alam yang tersedia bagi suatu bangsa melimpah tanpa adanya sumber daya manusia (SDM) yang tangguh, maka sulit diharapkan untuk berhasil membangun bangsa itu sendiri. ${ }^{2}$

Balita merupakan kelompok usia yang paling menderita akibat kurang gizi dan jumlahnya dalam populasi cukup besar. Kurang gizi pada balita dapat berakibat gagal tumbuh kembang serta meningkatkan kesakitan dan kematian. ${ }^{3}$ Pada tahun 2005, persentase anak yang mengalami gizi kurang pada usia 0 sampai 4 bulan terjadi pada beberapa negara, diantaranya Amerika Latin dan negara maju (5\%), Afrika dan negara berkembang (15 - 30\%) sedangkan persentase untuk Asia hampir sama dengan Afrika. ${ }^{4}$ Hal ini juga terbukti dari hasil riset yang menunjukkan bahwa prevalensi (angka kejadian) gizi kurang secara nasional tahun 2013 masih cukup tinggi yaitu 5,3\%. ${ }^{5}$

Di Kota Padang, balita gizi kurang pada tahun 2011 sebanyak 518 balita. $^{6}$ Masalah kekurangan gizi dapat terjadi di semua daerah, baik daerah perkotaan maupun pesisir pantai, begitu pula halnya di Kelurahan Air Tawar Barat, Kecamatan Padang Utara. Berdasarkan pendataan dari Dinkes Kota Padang tahun 2012, diantara kecamatan lainnya, kelurahan ini termasuk daerah dengan status gizi kurang yang tinggi $(8,6 \%)$ setelah kecamatan bungus $(8,7 \%) .^{7}$ Menurut Suhardjo pada tahun 2003, terdapat beberapa faktor yang dapat mempengaruhi asupan gizi antara lain faktor langsung konsumsi makanan dan penyakit infeksi serta faktor tidak langsung antara lain tingkat pendapatan, pengetahuan tentang gizi dan tingkat pendidikan. ${ }^{8}$ Tingkat pengetahuan setiap orang tentang gizi tidak sama. Hal ini terjadi karena berbagai faktor seperti umur, pendidikan, pekerjaan, pengalaman dan lingkungan. ${ }^{9}$ Asupan gizi kurang menyebabkan balita akan terganggu kesehatan dan perkembangannya. Sebaliknya, asupan gizi yang baik akan berimplikasi terhadap keseluruhan tumbuh kembang. Untuk mendapatkan asupan gizi yang baik dibutuhkan sekaligus ekonomi yang baik dan pengetahuan yang baik. Menurut penelitian Linda pada tahun 2012, pengetahuan gizi ibu yang rendah dapat menghambat usaha perbaikan gizi yang baik pada keluarga, tetapi pengetahuan yang baik tidak selalu bisa merubah masyarakat menjadi keluarga sadar gizi dalam arti tidak hanya mengetahui gizi saja tetapi harus mengerti dan mau berbuat untuk mengaplikasikan pengetahuan tersebut dalam menyediakan dan menyajikan makanan bergizi bagi semua anggota keluarga. ${ }^{10}$

Proporsi anak gizi kurang berbanding terbalik dengan pendapatan. Semakin kecil pendapatan penduduk, semakin tinggi persentase anak yang kekurangan gizi, sebaliknya semakin tinggi pendapatan semakin kecil persentase gizi buruk. ${ }^{11}$ Daya beli keluarga sangat ditentukan oleh tingkat pendapatan keluarga. Orang miskin biasanya akan membelanjakan sebagian besar pendapatannya untuk makanan. Hal ini menyebabkan ketersediaan makanan ditingkat keluarga juga kurang yang pada akhirnya berakibat pada tingkat konsumsi keluarga lebih rendah dari kecukupan. ${ }^{8}$

\section{METODE}

Penelitian ini menggunakan metode analitik dengan pendekatan cross sectional. Waktu penelitian dilaksanakan dari Juli 2014 - Januari 2015. Populasi penelitian adalah ibu yang memiliki anak usia 1 - 5 tahun dari keluarga nelayan di Kelurahan Air Tawar Barat Kota Padang yang berjumlah 24 orang. Sampel diambil dengan metode total sampling berjumlah 21 orang ibu karena dua ibu pindah rumah dan satu ibu tidak berada dirumah ketika dilakukan penelitian.

Variabel dependen penelitian adalah status gizi yang dinyatakan berdasarkan berat badan terhadap tinggi badan (BB/TB) sesuai dengan pedoman ringkas antropometri dan penentuan gizi keputusan menteri 2011. ${ }^{12}$ BB/TB dinyatakan dalam Standar Deviasi (SD) yang diklasifikasikan sebagai sangat kurus ( $\leq-3 S D)$, kurus (-3SD sampai dengan $<2 S D$ ), normal (-2 SD 
sampai dengan 2 SD), dan gemuk (> 2 SD). Alat yang digunakan untuk menimbang berat badan anak yaitu timbangan injak dengan kapasitas $150 \mathrm{~kg}$ dan ketelitian 0,1 gr. Alat yang digunakan untuk mengukur tinggi badan anak adalah microtoise dengan kepekaan sampai $0,1 \mathrm{~cm}$. Variabel independen adalah tingkat pengetahuan ibu dan tingkat ekonomi yang dikumpulkan datanya dengan kuesioner.

Pengolahan data yang dilakukan yaitu memeriksa kelengkapan data dari kuesioner, memberikan kode pada setiap data variabel, data yang sudah diedit akan diberi kode diolah secara komputerisasi dan ditampilkan dalam distribusi sesuai dengan variabel yang diteliti, data diolah dengan sistem komputer dan memeriksa kembali data yang telah dimasukkan bahwa data tersebut telah bersih dari kesalahan. Analisis data terdiri dari analisis univariat dan bivariat. Analisis bivariat digunakan untuk mengetahui hubungan antara dua variabel dengan menggunakan uji korelasi rank Spearman dengan derajat kemaknaan $\mathrm{p}<0,005$.

HASIL

Tabel 1. Distribusi frekuensi umur ibu, pendidikan ibu, pekerjaan ibu, jumlah anak dan umur balita pada keluarga nelayan di Kelurahan Air Tawar Barat Kota Padang

\begin{tabular}{|c|c|c|c|}
\hline No. & Karakteristik & $\begin{array}{c}\text { Frekuensi } \\
(n=21)\end{array}$ & $\begin{array}{c}\text { Persen } \\
(\%)\end{array}$ \\
\hline \multirow[t]{4}{*}{1.} & Umur lbu (tahun) & & \\
\hline & $20-25$ & 6 & 28,6 \\
\hline & $26-30$ & 8 & 38,1 \\
\hline & $31-35$ & 7 & 33,3 \\
\hline \multirow[t]{4}{*}{2.} & Pendidikan Ibu & & \\
\hline & Tamat SD & 5 & 23,8 \\
\hline & Tamat SMP & 7 & 33,3 \\
\hline & Tamat SMA & 9 & 42,9 \\
\hline \multirow[t]{3}{*}{3.} & Pekerjaan Ibu & & \\
\hline & Tidak Bekerja & 19 & 90,5 \\
\hline & Bekerja & 2 & 9,5 \\
\hline \multirow[t]{3}{*}{4.} & Jumlah Anak & & \\
\hline & $\leq 2$ Orang & 15 & 71,4 \\
\hline & $>2$ Orang & 6 & 28,6 \\
\hline \multirow[t]{5}{*}{5.} & Umur Balita (bulan) & & \\
\hline & $12-24$ & 16 & 76,2 \\
\hline & $25-36$ & 4 & 19,0 \\
\hline & $37-48$ & 0 & 0 \\
\hline & $49-60$ & 1 & 4,8 \\
\hline
\end{tabular}

Pada Tabel 1 terlihat bahwa responden ibu yang paling banyak adalah kelompok umur 26-30 tahun sebanyak $38,1 \%$. Tingkat pendidikan ibu yang terbanyak adalah SMA sebanyak 42,9\%. Dari 21 orang ibu yang menjadi responden, 90,5\% responden tidak bekerja atau sebagai ibu rumah tangga. Jumlah anak $\leq 2$ orang sebanyak $71,4 \%$. Umur balita yang paling banyak adalah kelompok umur 12- 24 bulan sebanyak $76,2 \%$

Tabel 2. Distribusi frekuensi status gizi balita pada keluarga nelayan di Kelurahan Air Tawar Barat Kota Padang

\begin{tabular}{|c|c|c|c|}
\hline $\begin{array}{c}\text { Status Gizi } \\
\text { Balita }\end{array}$ & Frekuensi & Nilai & $\begin{array}{c}\text { Persen } \\
\text { (\%) }\end{array}$ \\
\hline Gemuk & 9 & $>2 \mathrm{SD}$ & 0 \\
\hline Normal & 19 & $\begin{array}{l}-2 \text { SD sampai } \\
\text { dengan } 2 \text { SD }\end{array}$ & 90,5 \\
\hline Kurus & 2 & $\begin{array}{c}-3 \text { SD sampai } \\
\text { dengan }<-2 \text { SD }\end{array}$ & 9,5 \\
\hline $\begin{array}{l}\text { Sangat } \\
\text { Kurus }\end{array}$ & 0 & $\leq 3 \mathrm{SD}$ & 0 \\
\hline Jumlah & 21 & & 100 \\
\hline
\end{tabular}

Tabel 2 memperlihatkan bahwa pada umumnya $(90,5 \%)$ balita pada keluarga nelayan di Kelurahan Air Tawar Barat Kota Padang balita berstatus gizi normal.

Tabel 3. Distribusi frekuensi tingkat pengetahuan ibu pada keluarga nelayan di Kelurahan Air Tawar Barat Kota Padang

\begin{tabular}{ccc}
\hline Tingkat Pengetahuan Ibu & Frekuensi & $\begin{array}{c}\text { Persen } \\
\text { (\%) }\end{array}$ \\
\hline Rendah & 11 & 52,3 \\
Tinggi & 10 & 46,7 \\
\hline Jumlah & 21 & 100 \\
\hline
\end{tabular}

Berdasarkan Tabel 3 terlihat bahwa lebih dari separuh (52,3\%) ibu balita pada keluarga nelayan di Kelurahan Air Rawar Barat Kota Padang memiliki pengetahuan rendah. 
Tabel 4. Distribusi frekuensi tingkat ekonomi pada keluarga nelayan di Kelurahan Air Tawar Barat Kota Padang

\begin{tabular}{ccc}
\hline Tingkat Ekonomi Keluarga & Frekuensi & $\begin{array}{c}\text { Persen } \\
\text { (\%) }\end{array}$ \\
\hline Miskin & 20 & 95,2 \\
Tidak Miskin & 1 & 4,8 \\
\hline Jumlah & 21 & 100 \\
\hline
\end{tabular}

Tabel 4 memperlihatkan bahwa pada umumnya $(95,2 \%)$ keluarga nelayan di Kelurahan Air Tawar Barat Kota Padang memiliki tingkat ekonomi dalam katergori miskin.

Tabel 5. Analisa hubungan tingkat pengetahuan ibu dengan status gizi balita pada keluarga nelayan di Kelurahan Air Tawar Barat Kota Padang

\begin{tabular}{|c|c|c|c|c|c|c|}
\hline \multirow{3}{*}{$\begin{array}{c}\text { Status } \\
\text { Gizi }\end{array}$} & \multicolumn{4}{|c|}{ Tingkat Pengetahuan Ibu } & \multirow{3}{*}{$\mathbf{p}$} & \multirow{3}{*}{$r$} \\
\hline & \multicolumn{2}{|c|}{ Rendah } & \multicolumn{2}{|c|}{ Tinggi } & & \\
\hline & $\mathbf{n}$ & $\%$ & $\mathbf{n}$ & $\%$ & & \\
\hline Kurus & 2 & 100 & 0 & 0 & 0,638 & $-0,109$ \\
\hline Normal & 9 & 47,4 & 10 & 52,6 & & \\
\hline Jumlah & 11 & 52,4 & 10 & 47,6 & & \\
\hline
\end{tabular}

Pada Tabel 5 diketahui bahwa persentase balita dengan dengan status gizi kurus hanya terdapat pada ibu dengan pengetahuan rendah dan persentase balita dengan gizi normal banyak pada balita yang memiliki ibu dengan pengetahuan tinggi. Sedangkan, pada balita dengan gizi sangat kurus dan gizi gemuk tidak ditemukan pada daerah penelitian. Analisis bivariat yang dilakukan dengan menggunakan uji korelasi Rank Spearman didapatkan nilai p > 0,005 dan nilai koefisien korelasi ( $r$ ) -1,09. Hal ini menunjukkan bahwa tidak terdapat hubungan antara tingkat pengetahuan ibu dengan status gizi balita pada keluarga nelayan.

Tabel 6. Analisa Hubungan Tingkat Ekonomi Keluarga dengan Status Gizi Balita pada Keluarga Nelayan di Kelurahan Air Tawar Barat Kota Padang

\begin{tabular}{|c|c|c|c|c|c|c|}
\hline \multirow{3}{*}{$\begin{array}{c}\text { Status } \\
\text { Gizi }\end{array}$} & \multicolumn{4}{|c|}{ Tingkat Pengetahuan Ibu } & \multirow{3}{*}{$\mathbf{p}$} & \multirow{3}{*}{$\mathbf{r}$} \\
\hline & \multicolumn{2}{|c|}{ Miskin } & \multicolumn{2}{|c|}{$\begin{array}{c}\text { Tidak } \\
\text { Miskin }\end{array}$} & & \\
\hline & $\mathbf{n}$ & $\%$ & $\mathbf{n}$ & $\%$ & & \\
\hline Kurus & 2 & 100 & 0 & 0 & 0,868 & $-0,039$ \\
\hline Normal & 18 & 94,7 & 1 & 5,3 & & \\
\hline Jumlah & 20 & 95,2 & 1 & 4,8 & & \\
\hline
\end{tabular}

Berdasarkan Tabel 6 diketahui bahwa balita dengan status gizi kurus hanya terdapat pada keluarga dengan tingkat ekonomi miskin dan balita dengan status gizi normal paling banyak juga pada keluarga dengan tingkat ekonomi miskin. Sedangkan, pada balita dengan gizi sangat kurus dan gemuk tidak ditemukan pada daerah penelitian. Analisis bivariat yang dilakukan dengan menggunakan uji korelasi rank Spearman didapatkan nilai $p>0,005$ dan nilai koefisien korelasi ( $r$ ) -0,039. Hal ini menunjukkan bahwa tidak terdapat hubungan antara tingkat ekonomi dengan status gizi balita pada keluarga nelayan di Kelurahan Air Tawar Barat Kota Padang.

\section{PEMBAHASAN}

Responden ibu paling banyak berada pada kelompok umur 26 - 30 tahun yaitu $38,1 \%$. Terdapat pergeseran umur di kalangan nelayan. Informasi yang didapatkan menyatakan bahwa nelayan di kawasan Kelurahan Air Tawar Barat dahulunya terdiri dari berbagai umur. Sekarang kebanyakan nelayan berusia lebih dari 40 tahun, hal ini tentu berdampak pada jumlah sampel penelitian. Saat ini, menjadi nelayan tidak lagi menjadi sumber mata pencaharian. Dahulu pada saat menjaring ikan, banyak sekali ikan terjaring tetapi sekarang jaring banyak berisi sampah (organik maupun anorganik), tentu hal ini akan berdampak pada penghasilan nelayan dan ditinjau dari pekerjaan ibu hampir semuanya tidak bekerja, yaitu sebanyak 90,5\%. Hal ini menggambarkan bahwa untuk memenuhi kebutuhan harian bergantung kepada ayah yang bekerja sebagai nelayan.

Tingkat pendidikan ibu mayoritas sudah baik, yaitu sebesar $42,9 \%$ tamat SMA. Tingkat pendidikan orang tua turut menentukan status gizi anak karena pendidikan sangat mempengaruhi seseorang untuk memahami dan menerima informasi tentang gizi. ${ }^{13}$ Orang tua yang memiliki pendidikan yang tinggi lebih berorientasi pada tindakan preventif, tahu lebih banyak tentang masalah kesehatan, dan memiliki status kesehatan yang lebih baik. $^{14}$ Semakin tinggi pendidikan ibu diharapkan ibu memiliki pengetahuan yang lebih baik dalam mengasuh anak. ${ }^{15}$

Status gizi balita dari keluarga nelayan yang diukur secara Antropometri didapatkan dua balita 
dengan status gizi kurus, 19 balita berstatus gizi normal dan tidak ditemukan balita dengan gizi sangat kurus dan gemuk. Walupun dikategorikan sebagai normal, status gizi normal ini berada pada kelompok batas bawah (-3 SD sampai dengan <-2 SD). Dalam penelitian usia ibu, pekerjaan ibu, dan usia perkawinan juga mempengaruhi status gizi balita. Menurut Giglia tahun 2012 menyatakan bahwa usia juga dapat mempengaruhi tingkat pengetahuan. ${ }^{16}$ Hasil penelitian menunjukkan bahwa distribusi responden berdasarkan karakterisktik umur yang terbanyak yaitu umur 26-30 tahun (38,1\%). Ini menggambarkan bahwa ibu umumnya berada pada masa reproduksi dan masa awal menikah atau masa baru memiliki anak. Ditemukan sebanyak 15 ibu $(71,4 \%)$ yang memiliki $\leq 2$ orang anak, Pada keadaan ini ibu cenderung untuk lebih memperhatikan anaknya. Terdapat 90,5\% ibu yang tidak bekerja ini berarti waktu ibu dihabiskan untuk mengatur dan mengasuh anaknya di rumah.

Pengetahuan adalah hasil dari tahu dan terjad setelah orang melakukan penginderaan terhadap objek. Sebagian besar pengetahuan manusia diperoleh melalui mata dan telinga. Pengetahuan merupakan hal yang dominan dalam membentuk tindakan seseorang. ${ }^{9}$ Pengetahuan tidak hanya didapat dari sekolah saja, melainkan pengetahuan juga dapat diperoleh dari pengalaman hidup seharihari terutama pengetahuan ibu tentang gizi. Semakin banyak pengetahuan gizinya semakin diperhitungkan jenis dan jumlah makanan yang dipilih untuk dikonsumsi. Untuk ibu yang tidak mempunyai cukup pengetahuan gizi, akan memilih makanan yang paling menarik pancaindra dan tidak mengadakan pilihan berdasarkan pilihan berdasarkan nilai gizi makanan. Sebaliknya orang yang semakin banyak pengetahuan gizi, lebih banyak mempergunakan pertimbangan rasional dan pengetahuan tentang nilai gizi makanan tersebut. $^{17}$ Tingkat pengetahuan gizi ibu tidak selalu menyebabkan asupan energi anak sesuai dengan angka kecukupan yang dianjurkan. Hal ini disebabkan karena ibu tidak bisa menyediakan makanan yang cukup beragam dan sesuai dengan kebutuhan masing-masing anggota keluarga. Penyebab lain diantaranya adalah karena sikap dan prilaku ibu terhadap gizi tidak sejalan dengan pengetahuan gizinya. ${ }^{10}$ Analisis bivariat yang dilakukan dengan menggunakan uji korelasi rank Spearman didapatkan nilai $p>0,005$ dan nilai koefisien korelasi $(r)-0,109$. Hal ini menunjukkan bahwa tidak terdapat hubungan antara tingkat pengetahuan ibu dengan status gizi balita pada keluarga nelayan di Kelurahan Air Tawar Barat Kota Padang. Hasil penelitian serupa yang dilakukan oleh Morani (2008) pada balita di Kecamatan Kotaruopan Kabupaten Mandailing Natal, juga mengatakan bahwa tidak terdapat hubungan yang bermakna antara tingkat pengetahuan ibu terhadap status gizi balita. ${ }^{18} \mathrm{Hal}$ ini disebabkan karena banyak sekali yang bisa mempengaruhi gizi balita, seperti ketersediaan pangan, pola konsumsi, penyakit infeksi, peran serta tokoh masyarakat, dan aktivitas ibu. Menurut Meikawati dan Hersoelistyorini (2008), pola asuh ibu dan keluarga terhadap balita dan jumlah anggota keluarga juga mempengaruhi status gizi balita. $^{19}$ Adanya perkembangan teknologi saat ini ibu dapat dengan mudah mengetahui informasi dari berbagai media, sehingga ibu dapat meningkatkan pengetahuannya. ${ }^{20}$

Tingkat ekonomi keluarga merupakan suatu penentu status gizi yang dapat mempengaruhi status gizi balita. Kemiskinan menduduki posisi pertama pada masyarakat yang menyebabkan gizi kurang. Masalah utama pada masyarakat miskin adalah pendapatan yang rendah sehingga tidak dapat mencukupi kebutuhan dasar normal. Masyarakat miskin akan cendrung tidak mempunyai cadangan makanan karena daya beli yang rendah dan berlaku sebaliknya. ${ }^{13}$ Masyarakat nelayan cenderung untuk menjual hasil tangkapan dibanding mengkonsumsi sendiri hasil yang mereka dapat, dengan tujuan mendapatkan sejumlah uang untuk membeli bahan makanan yang secara kuantitas mungkin lebih tapi rendah kualitasnya, disamping itu juga dapat digunakan untuk memenuhi kebutuhan yang bersifat non pangan seperti peralatan elektronik rumah tangga dan perhiasan. ${ }^{21}$ Balita dengan status gizi kurus hanya terdapat pada keluarga dengan tingkat ekonomi miskin dan balita dengan status gizi normal paling banyak juga pada keluarga dengan tingkat ekonomi miskin. Sedangkan, pada balita dengan gizi sangat kurus dan gemuk tidak ditemukan pada daerah penelitian. Analisis bivariat yang dilakukan dengan menggunakan uji korelasi rank Spearman didapatkan nilai $p>0,005$ 
dan nilai koefisien korelasi ( $r$ ) -0,039. Hal ini menunjukkan bahwa tidak terdapat hubungan antara tingkat ekonomi dengan status gizi balita pada keluarga nelayan di Kelurahan Air Tawar Barat Kota Padang. Hasil peneltian serupa dengan penelitian Khair (2007) yang dilakukan pada anak sekolah dasar di Kelurahan Pasia Nan tigo, Kec. Koto Tangah, Padang, Sumatera Barat. Pendapatan yang rendah ternyata cenderung tidak menjadi kendala bagi keluarga untuk menjadi balita berstatus gizi baik, selama distribusi pangan keluarga lebih mengutamakan memenuhi kebutuhan anak daripada anggota keluarga lain. ${ }^{22}$

\section{KESIMPULAN}

Tidak terdapat hubungan yang bermakna antara tingkat pengetahuan ibu dan tingkat ekonomi keluarga dengan status gizi balita Kelurahan Air Tawar Barat Kota Padang.

\section{UCAPAN TERIMA KASIH}

Terima kasih kepada semua yang telah memberikan kritik, saran dan bimbingan dalam penelitian ini, juga terima kasih kepada semua responden yang telah bersedia berpartisipasi dalam penelitian ini.

\section{DAFTAR PUSTAKA}

1. Kemenkes RI. Riset kesehatan dasar indonesia (RISKESDAS) 2013. Jakarta: Badan Penelitian dan Pengembangan Kesehatan Kementerian Kesehatan RI; 2013.

2. Tanuwijaya S. Kebutuhan dasar tumbuh kembang anak. Dalam: (Ikatan Dokter Indonesia) Tumbuh Kembang Anak dan Remaja. Edisi ke-1. Jakarta: Sagung Seto; 2002. hlm.13.

3. Ony L, Dian KH. Hubungan pendidikan dan pekerjaan orang tua serta pola asuh dengan status gizi balita di kota dan kabupaten Tangerang, Banten. Jurnal Fiskes Uhamka. 2011;134-41.

4. Diana FM. Hubungan konsumsi asam lemak dengan perkembangan anak usia 2- 5 tahun di Kecamatan Nanggalo Kota Padang (tesis). Padang: Universitas Andalas; 2009.
5. Dinas Kesehatan Provinsi Sumbar. Profil kesehatan tahun 2013. Padang: Dinas Kesehatan Provinsi Sumbar; 2013.

6. Dinas Kesehatan Kota Padang. Profil kesehatan tahun 2011. Padang: Dinas Kesehatan Kota Padang; 2012.

7. Dinas Kesehatan Kota Padang. Profil kesehatan tahun 2012. Padang: Dinas Kesehatan Kota Padang; 2013.

8. Suhardjo. Berbagai cara pendidikan gizi. Jakarta: Bumi Aksara; 2003.

9. Notoatmodjo S. IImu kesehatan masyarakat, prinsip-prinsip dasar. Jakarta: Rineka Cipta; 1997.

10. Linda M. Hubungan tingkat pengetahuan ibu dan ketahanan pangan dengan asupan zat gizi serta kaitannya dengan status gizi anak sekolah dasar di Kecamatan Sangir Batang Hari Kabupaten Solok Selatan Tahun 2012 (skripsi). Padang: Universitas Andalas; 2012.

11. Adisasmito W. Sistem kesehatan. Jakarta: Raja Grafindo Persada; 2007.

12. Kemenkes RI Direktorat Jenderal Bina Gizi dan Kesehatan lbu dan Anak. Standar antropometri penilaian status gizi anak. Jakarta: Direktorat Bina Gizi; 2011

13. Suhardjo. Perencanaan pangan dan gizi. Edisi ke1. Jakarta: Bumi Aksara; 2005.

14. Timmrect CT. Epidemiologi suatu pengantar. Jakarta: EGC; 2005

15. Engle PL, Bentley M, Pelto G. The role of care in nutrition programmers: current research and a research Ganda. Proceeding of the nutrition society. Food and Nutrition Buletin. 2000;(59):2535.

16. Giglia M. Knowledge and attitudes of obesity in university students. Journal University of Chester. 2012.

17. Sediaoetama AD. Ilmu gizi untuk mahasiswa dan profesi Jilid II. Jakarta: Dian Rakyat; 2010.

18. Morani W. Hubungan tingkat pengetahuan ibu tentang makanan bergizi balita di Kec. Kotanopan Kab. Mandailing Natal. Jurnal Universitas Sumatera Utara. 2011.

19. Meikawati W, Wikana Hersoelistyorini W. Hubungan karakterisitk ibu dan tingkat ekonomi 
sosial keluarga terhadap kasus gizi buruk pada balita di Kelurahan Tandang Kecamatan Tembalang. Jurnal Universitas Muhammadiyah; Semarang; 2008.

20. Astuti FD, Sulistyowati TF. Hubungan tingkat pendidikan ibu dan tingkat pendapatan keluarga dengan status gizi anak prasekolah dan sekolah dasar di Kecamatan Godean. ISSN: 1978 - 0575.
2012;7(1):15-20.

21. Putri EK. Hubungan tingkat pendidikan ibu tingkat ekonomi keluarga nelayan dengan status gizi balita di Desa Pauh Barat Kab. Padang Pariaman (skripsi). Padang: Universitas Andalas; 2002.

22. Khair NE. Status gizi murid kelas I SD di Kelurahan Pasia Nan Tigo Kec. Koto Tangah (skripsi). Padang: Universitas Andalas; 2007. 